\title{
Anti-Elastase Activity of Rumput Teki (Cyperus rotundus L.) Rhizome Extract
}

\author{
Isni Rizqi Putri, Rosita Handayani, Berna Elya*
}

Isni Rizqi Putri, Rosita Handayani, Berna Elya*

Department of PharmacognosyPhytochemistry, Faculty of Pharmacy, Universitas Indonesia, Depok, 16424 West Java, INDONESIA.

\section{Correspondence}

\section{Berna Elya}

Department of Pharmacognosy-

Phytochemistry, Faculty of Pharmacy,

Universitas Indonesia, Depok 16424, West Java, INDONESIA.

Phone no: +6281314161497;

E-mail: berna.elya@farmasi.ui.ac.id

History

- Submission Date: 22-10-2018;

- Review completed: 06-04-2019;

- Accepted Date: 21-04-2019.

DOI : 10.5530/pj.2019.11.119

Article Available online

http://www.phcogj.com/v11/i4

\section{Copyright}

(c) 2019 Phcogj.Com. This is an openaccess article distributed under the terms of the Creative Commons Attribution 4.0 International license.

\begin{abstract}
Objective: Excessive reactive oxygen species (ROS) often trigger the activation of elastase to degrade the elastin, an extracellular matrix (ECM) protein that provides resilience and elasticity of the skin. Therefore, the inhibition of elastase could reduce the wrinkles formation in the skin. Rumput teki (Cyperus rotundus L.) is used empirically to increase the skin elasticity but the scientific justification was still limited. This study aimed to determine the activity of Cyperus rotundus $L(C y R)$ in inhibiting the elastase activity. Methods: Extraction of CyR was performed by maceration method using $70 \%$ ethanol. The inhibition percentage and $I C_{50}$ were determined by the colorimetric method using porcine pancreatic elastase (PPE) and N-Succ-(Ala)3-p- nitroanilide (SANA) as substrate. Phytochemical screening, determination of Total Phenolic content (TPC), and Total Flavonoid Content (TFC) were also performed to calculate the level of phenolic and flavonoid content in the sample. Results: The extract of CyR rhizomes contained TPC and TFC of $62.72 \mathrm{mgGAE} / \mathrm{g}$ and $10.72 \mathrm{mgEQ} / \mathrm{g}$ extract respectively and showed an inhibitory activity on elastase with $\mathrm{IC}_{50}$ of $178.72 \mu \mathrm{g} / \mathrm{mL}$, smaller than $\mathrm{IC}_{50}$ of quercetin as reference drug $(200.00 \mu \mathrm{g} / \mathrm{mL})$. Conclusion: This finding suggested that extract of CyR rhizomes could be used as elastase inhibitor but the further research still needs to be developed.
\end{abstract}

Key words: Cyperus rotundus L., Elastase, Skin ageing, Total phenolic content, Total flavonoid content.

\section{INTRODUCTION}

Skin aging is a complex biological phenomenon influenced by several factors including ultraviolet radiation to the skin. Ultraviolet radiation can increase the level of reactive oxygen species $(\mathrm{ROS})^{1}$, accelerating the activation of elastase to degrade elastin. Elastin is an important part of extracellular matrix that gives elasticity in the skin. ${ }^{2}$ Excessive activation of the elastase may disrupt the elastin and trigger the wrinkles formation, therefore it affects to skin aging process. ${ }^{3}$ One way to prevent skin aging is by inhibiting elastase activity CyR rhizome is believed to have efficacy to prevent premature skin ageing both empirically and ethnobotanically. ${ }^{4,5}$ The rhizome of Cyperus rotundus has a therapeutic effect to prevent premature skin ageing induced by UV light. ${ }^{6,7}$ In the previous research, Cyr rhizome shown to have chemical content of polyphenols such as flavonoids, quercetin, luteolin, and kaempferol, catechins, and 3-hydroxy and 4-methoxy-benzoic acids. ${ }^{8,9}$ Polyphenolic compound showed elastase activity inhibition. Some of polyphenols found in plants such as catechin, epicatechin, epigallocatechin, boswellic acid, and flavonoid such as purpurin, quercetin, kaempferol and myricetin have an inhibitory activity against elastase. ${ }^{10-12}$

\section{MATERIALS AND METHODS}

\section{Materials}

Cyperus rotundus rhizomes were collected from Indonesian Spices and Medicinal Crops Research
Institute (BALITTRO). Quercetin (Sigma, Q4951), galic acid (Sigma, G7384), porcine pancreatic elastase (PPE; Sigma, E1250), substrate N-succinyl-(Ala) nitroanilide (Sigma, S4760), trizma base (Sigma, T1503), demineralized water, $70 \%$ ethanol, sodium hydroxide (Merck, Germany), hydrochloric acid, distilled water (Brataco, Indonesia).

\section{Methods}

\section{Extraction}

Dried rhizomes of CyR were extracted with ethanol $70 \%$ by maceration $(3 \times 24 \mathrm{~h})$. The extracts were filtered through Whatman paper and evaporated using a vacuum rotary evaporator at $60^{\circ} \mathrm{C}$ until it turned into a viscous extract.

\section{Elastase activity assay}

Elastase activity assay was performed using standard protocol provided by Sigma Aldrich with slight modification. Porcine pancreatic elastase (PPE) and $\mathrm{N}$-Succ-(Ala)3-p- nitroanilide (SANA) were used as enzyme and substrate. The reaction was monitored for $20 \mathrm{~min}$ at $25^{\circ} \mathrm{C}$. The absorbance of product, p-nitroaniline (pNA), was measured at $401 \mathrm{~nm}$ using microplate reader 96well ${ }^{\text {min }}$ (Versa Max ELISA Microplate Reader, USA). The reaction mixture contained $0.2 \mathrm{M}$ Tris- $\mathrm{HCl}$ buffer ( $\mathrm{pH} 8.0$ ), $0.8 \mathrm{U} / \mathrm{mL}$ PPE (porcie pancreatic elastase) $2.9 \mathrm{mM}$ SANA was pre-incubated for $20 \mathrm{~min}$ at $25^{\circ} \mathrm{C}$. Demineralized water was used as the blanks that replace the presence of PPE in the sample. Quercetin was used as a reference drug. The percentage of inhibition was

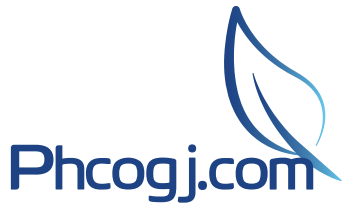

Cite this article: Putri IR, Handayani R, Elya B. Anti-Elastase Activity of Rumput Teki (Cyperus rotundus L.) Rhizome Extract. Pharmacog J. 2019;11(4):754-8. 
calculated as: Inhibition $(\%)=(1-\mathrm{B} / \mathrm{A}) \times 100$, where $\mathrm{A}$ is the absorbance of sample without inhibitor (reference drug or extract), and $B$ is the absorbance of sample with inhibitor. $\mathrm{IC}_{50}$ values were obtained from the regression linear equation.

\section{Phytochemical screening}

Qualitative method was performed with with Mayer, Dragendroff, and Bouchardat reagents to detect the presence of alkaloid. ${ }^{13-16}$ Willstatter reaction for flavonoid. ${ }^{14}$ gelatin test and ferrous (III) chloride test for tannin..$^{15,16}$ frothing test for saponin. ${ }^{14}$ bortranger test for antaquinone, Liebermann-Burchard test for steroid and triterpenoid. ${ }^{13,15}$

\section{Thin layer chromatography analysis}

Chromatography analysis on CyR rhizome was performed using quercetin and gallic acid as reference compound. $20 \mu \mathrm{L}$ sample solution $2000 \mu \mathrm{g} / \mathrm{mL}$ (in methanol) and $2 \mu \mathrm{L}$ reference solution $0.1 \%$ (in methanol) were spotted into silica gel $\mathrm{GF}_{254}$ plate, eluted with mobile phase of chloroform:acetone:formic acid (8:4:2), sprayed with $\mathrm{AlC}_{3} 5 \%$ (in ethanol), and observed under UV at $366 \mathrm{~nm}$.

\section{Determination of TPC}

TPC determination was performed on the 96-well microplate using Folin-Ciocalteu method conducted by Bobo-Garcia et al. Gallic acid used as a standard. $25 \mu \mathrm{L}$ sample solution (contained CyR extract) or the standard solution (contained gallic acid) were mixed with 100 $\mu \mathrm{L}$ of 1:4 diluted Folin-Ciocalteu reagent (in ethanol), shaked for 60 seconds in a 96-well microplate and were incubated for $4 \mathrm{~min}$. Then the solution was added with $75 \mu \mathrm{L}$ of sodium carbonate solution (1\%). The solution was incubated within two hours at room temperature. The absorbance was measured at $\lambda 765 \mathrm{~nm}$.

\section{Determination of TFC}

Quercetin used as a standard with final concentration of 1, 2, 3, 4, 5 and $8 \mu \mathrm{g} / \mathrm{mL}$ in ethanol. To determine the flavonoid content, $0.5 \mathrm{~mL}$ solution of quercetin or extract was added to a test tube. The solution was mixed with $1.5 \mathrm{~mL}$ ethanol, $0.1 \mathrm{~mL} \mathrm{AlCl} 310 \%$ solution, $0.1 \mathrm{~mL}$ sodium acetate $1 \mathrm{M}$, and $2.8 \mathrm{~mL}$ distilled water. The mixture was centrifuged at $1000 \mathrm{rpm}$ for $10 \mathrm{~min}$ and then was incubated at room temperature for $30 \mathrm{~min}$. Sample containing the listed components except $\mathrm{AlCl}_{3}$ was replaced by the same quantity of distilled water for the blank. Absorbance was measured at $\lambda 430 \mathrm{~nm}$.

\section{RESULTS}

\section{Extraction}

The CyR rhizome was successfully extracted using the maceration method. From $300 \mathrm{~g}$ of CyR rhizome powder, the yields obtained were $36.66 \mathrm{~g}(12.22 \%)$.

\section{Elastase activity assay}

Inhibition of elastase activity of ethanolic extract was compared to Quercetin as a reference drug. Extract of CyR rhizomes showed an elastase activity inhibitory value with $\mathrm{IC}_{50}$ of $178.72 \mu \mathrm{g} / \mathrm{mL}$, smaller than of quercetin $(200.00 \mu \mathrm{g} / \mathrm{mL})$. This suggested that extract of CyR rhizomes had better elastase inhibitory activity than quercetin was demonstrated in Tables 2 and 3.

\section{Phytochemical screening}

Phytochemical screening of the ethanolic extract of CyR rhizomes was demonstrated in Table 1.

\section{Thin layer chromatography analysis}

Spot number 2 of CyR extract showed similarity in term of Rf value and spot colour with quercetin $(\mathrm{Rf}=0.81)$, and spot number 4 showed similarity with gallic acid $(\mathrm{Rf}=0.63)$. The result was in line to the previous study which showed that CyR contains flavonoid type of quercetin, myricetin, kaempferol, and apigenin (Figure 1). ${ }^{17}$

Table 1. The phytochemical screening result.

\begin{tabular}{cc}
\hline Compound groups & Result \\
\hline Flavonoids & + \\
Alkaloids & + \\
Terpenoids & + \\
Tannins & + \\
Saponins & + \\
Glycosides & + \\
Anthraquinone & - \\
\hline
\end{tabular}

Table 2. Elastase activity inhibition of quercetin as reference drug.

\begin{tabular}{|c|c|c|c|c|c|}
\hline Concentration $(\mu \mathrm{g} / \mathrm{mL})$ & $\%$ Inhibition & $\begin{array}{c}\text { Average } \% \text { inhibition } \\
\pm S D\end{array}$ & $\begin{array}{l}\text { Variation } \\
\text { coefficient }\end{array}$ & $\begin{array}{c}\text { Regression and } \\
\text { correlation value } \\
\text { equation }\end{array}$ & $I C_{50}(\mu \mathrm{g} / \mathrm{mL})$ \\
\hline \multirow{2}{*}{100} & 22.02 & \multirow{2}{*}{$19.17 \pm 2.85$} & \multirow{2}{*}{14.88} & & \multirow{10}{*}{200.00} \\
\hline & 16.32 & & & & \\
\hline \multirow{2}{*}{150} & 32.33 & \multirow{2}{*}{$34.38 \pm 2.05$} & \multirow{2}{*}{5.97} & & \\
\hline & 36.44 & & & & \\
\hline \multirow{2}{*}{200} & 49.85 & \multirow{2}{*}{$51.15 \pm 1.30$} & \multirow{2}{*}{2.54} & $y=0.3038 x-10.761$ & \\
\hline & 52.45 & & & $r=0.99925$ & \\
\hline \multirow{2}{*}{250} & 62.96 & \multirow{2}{*}{$65.97 \pm 3.00$} & \multirow{2}{*}{4.55} & & \\
\hline & 68.97 & & & & \\
\hline \multirow{2}{*}{300} & 76.68 & \multirow{2}{*}{$79.33 \pm 2.65$} & \multirow{2}{*}{3.34} & & \\
\hline & 81.98 & & & & \\
\hline
\end{tabular}


Table 3. Elastase activity inhibition of CyR rhizomes.

\begin{tabular}{|c|c|c|c|c|c|}
\hline Concentration $(\mu \mathrm{g} / \mathrm{mL})$ & $\%$ Inhibition & $\begin{array}{c}\text { Average } \% \text { Inhibition } \\
\pm \text { SD }\end{array}$ & Variation coefficient & $\begin{array}{c}\text { Regression and } \\
\text { Correlation Value } \\
\text { Equation }\end{array}$ & $I C_{50}(\mu \mathrm{g} / \mathrm{mL})$ \\
\hline \multirow{2}{*}{100} & 37.30 & \multirow{2}{*}{$36.42 \pm 1.25$} & \multirow{2}{*}{3.42} & & \multirow{10}{*}{178.12} \\
\hline & 35.54 & & & & \\
\hline \multirow{2}{*}{150} & 45.55 & \multirow{2}{*}{$43.92 \pm 2.31$} & \multirow{2}{*}{5.25} & & \\
\hline & 42.28 & & & & \\
\hline \multirow{2}{*}{200} & 54.67 & \multirow{2}{*}{$55.09 \pm 0.59$} & \multirow{2}{*}{1.08} & $y=0.1757 x+18.704$ & \\
\hline & 55.51 & & & $r=0.9974$ & \\
\hline \multirow{2}{*}{250} & 62.13 & \multirow{2}{*}{$63.05 \pm 1.31$} & \multirow{2}{*}{2.08} & & \\
\hline & 63.98 & & & & \\
\hline \multirow{2}{*}{300} & 72.62 & \multirow{2}{*}{$70.79 \pm 2.59$} & \multirow{2}{*}{3.66} & & \\
\hline & 68.96 & & & & \\
\hline
\end{tabular}

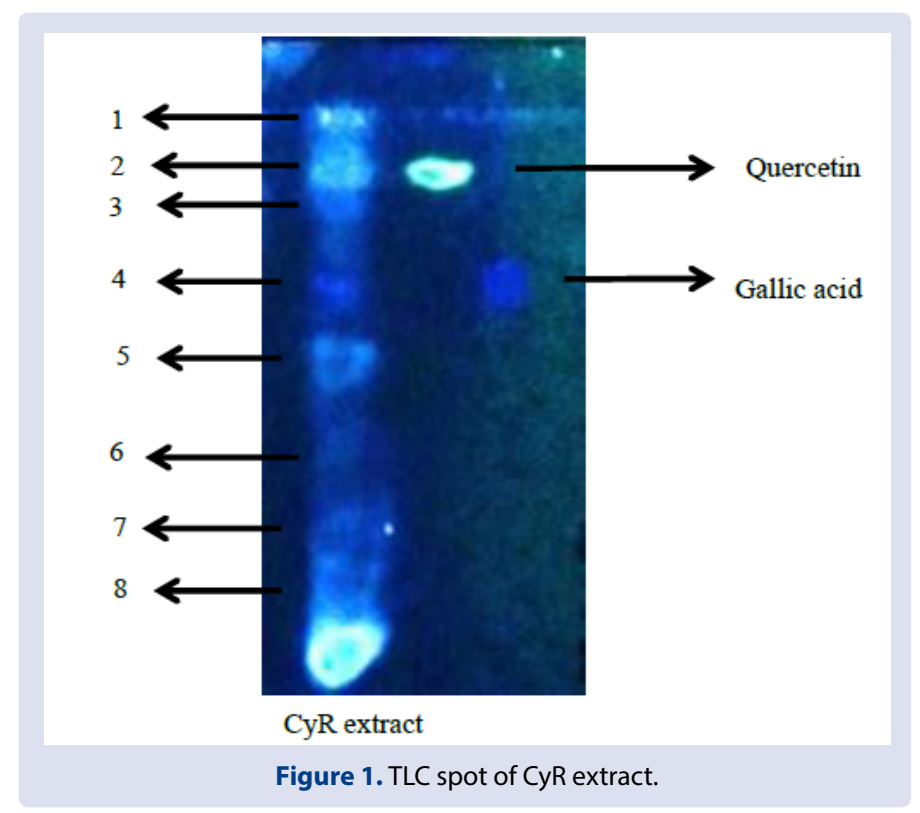

\section{Determination of TPC}

The graphic of sample absorbance $v s$ concentration produce linear regression $(r=0.99929)$. From the equation, TPC was estimated. The extract showed TPC of $62.72 \mathrm{mg} \mathrm{GAE} / \mathrm{g}$ extract).

\section{Determination of TFC}

The graphic of sample absorbance vs concentration produce linear regression linear $(r=0.99904)$. The TFC of was estimated of 10.72 mgEQ/g extract.

\section{DISCUSSION}

Inhibition of elastase activity by using N-succinyl- (Ala) 3 -nitroanilide as a substrat was chosen because it has specific proteolytic activity for pancreatic elastase and the reaction produces yellow p-nitroaniline as a product. $\mathrm{N}$-succinyl- (Ala) 3-nitroanilide also used as a substrate based on elastin structure which has residues of glycine, proline, alanine, leucine and valine. Alanine detected in tropoelastin as an elastin builder in human skin that some or most of the alanine residues can be degraded by elastase and $\mathrm{N}$-succinyl(Ala) 3-nitroanilide (SANA) has alanine that can degraded by elastase. Porcine pancreatic elastase (PPE) as an enzyme was chosen because PPE contains $89 \%$ amino acid that has similarity from amino acid in humans elastase. Based on previous studies, plant extracts from white tea which contain various chemical elements such as epigallokatekin-3-galat (EGCG), quercetin, kaempferol and gallic acid has been extensively studied and found to have anti-collagenase and anti-elastase activity. ${ }^{11}$ The chemical content of polyphenols such as catechins and epigallo catechins also found as an elastase inhibitor in green tea. Manilkara zapota (L.) sapodilla fruit, has been widely used as an herbal medicine in India. Ethanol extract from sapodilla fruit has a chemical content such as epikatekin, epigallokatekin, gallic acid, quercetin, myristetin and catechins, the last three pure compounds, quercetin, myristetin and catechins, reportedly inhibit collagenase and elastase activity. ${ }^{11}$

Polyphenols are compounds that play an important role in inhibiting elastase activity. ${ }^{10}$ The polyphenol content in plants has been proven to against free radicals that trigger skin aging process. Some researchers have investigated the chemical content of polyphenols found in plants such as flavonoids, catechins, epigallo catechins, gallic acid, boswellic acid, and purpurin have anti-elastase activity. ${ }^{11,12}$ In the tests carried out, it can be seen that Cyr rhizome contained phenolic compounds which expressed as TPC of 62.72 $\mathrm{mg} \mathrm{GAE} / \mathrm{g}$, and flavonoid compounds which expressed as TFC of $10.72 \mathrm{mgE} / \mathrm{g}$ extract.

Inhibition of elastase activity occurred due to the presence of polyphenolic compounds found in the rhizomes of CyR. Polyphenols bind to enzymes by hydrogen bond formation between hydroxyl and amino acid groups in the enzymes, resulting enzyme denaturation through catalytic activity site elimination. The binding process triggers hydrophobic effect that produced complexes or precipitated aggregates and not dissolved in water so that the enzyme will be denatured. In this 
study using PPE (Porcine Pancreatic Elastase), polyphenols were likely to form hydrogen bonds with amino acid side chains found in enzymes known as catalytic triads formed by serine, histidine and aspartate residues. $^{18}$

Based on previous study, CyR rhizome can prevent premature aging of the skin with the ability to brighten and soften the skin. Due to chronic ultraviolet exposure, collagen and elastase in the dermis will denature, leading to wrinkles and photoaging of the skin. CyR also has a therapeutic effect in the form of prevention of skin aging induced $\mathrm{UV} ., 7$

\section{CONCLUSION}

This is the first study to investigate the anti-elastase of CyR rhizome extract. Based on this study, extract of Cyr rhizomes showed an inhibitory of elastase activity $\left(\mathrm{IC}_{50} 178.72 \mu \mathrm{g} / \mathrm{mL}\right.$ ), smaller than $\mathrm{IC}_{50}$ of quercetin as reference drug $(200.00 \mu \mathrm{g} / \mathrm{mL})$. The preliminary results suggest that the activity of the elastase inhibitors from CyR rhizome may be helpful in the treatment of skin aging. Further investigations on the properties of CyR are needed to refine and purify the compound, as well as to determine its mechanism against elastase activity.

\section{ACKNOWLEDGEMENT}

This research was supported by Hibah Tugas Akhir Doktor UI Tahun 2018 provided by Universitas Indonesia.

\section{CONFLICTS OF INTEREST}

The Author have no conflicts of interest to declare.

\section{ABBREVIATIONS}

CyR: Cyperus Rotundus, SANA: N-Succ-(Ala)3-p- nitroanilide; PPE: Porcine Pancreatic Elastase; GAE: Gallic Acid Equivalent; QE: Quercetin Equivalent, TPC: Total Phenolic Content, TFC: Total Flavonoid Content. This finding suggested that extract of CyR rhizomes could be used as elastase inhibitor but the further research still needs to be developed.

\section{REFERENCES}

1. Rittié L. UV-light-induced signal cascades and skin aging. Ageing Research Reviews. 2002;1(4):705-20.

2. Onar HC, Yusufoglu A, Turker G, Yanardag R. Elastase, tyrosinase and lipoxygenase inhibition and antioxidant activity of an aqueous extract from Epilobium angustifolium L. Leaves. J Med Plant Res. 2012;6(5):716-26.
3. Wiedow O, Schröder JM, Gregory H, Young JA, Christophers E. Elafin: an elastasespecific inhibitor of human skin. Purification, characterization, and complete amino acid sequence. J Biol Chem. 1990;265:14791-5.

4. Peerzada A, Ali H, Naeem M, Latif M, Bukhari A, Tanveer A. Cyperus rotundus: Traditional uses, phytochemistry, and pharmacological activities. J Ethnopharmacol. 2015;174:540-60.

5. Sharma R, Gupta R. Cyperus rotundus extract inhibits acetylcholinesterase activity from animal and plants as well as inhibits germination and seedling growth in wheat and tomato. Life Sciences. 2007:80:2389-92.

6. Al-Snafi AE. A review on Cyperus rotundus A potential medicinal plant. IOSR J Pharmacy. 2016;6(2):2250-3013

7. Seo WG, Pae HO, On GS, Chai KY, Kwon TO, Yun YG, et al. Inhibitory effects of methanol extract of Cyperus rotundus rhizomes on nitric oxide and superoxide productions by murine macrophage cell line, RAW 264.7 cells. J Ethnopharmacol. 2011;76(1):59-64.

8. Ju Ying dan Xiao B. Chemical constituents of Cyperus rotundus L. and their inhibitory effects on uterine fibroids. Department of Obstetrics and Gynecology, Tangdu Hospital, The Fourth Military Medical University. 2016;6(1):8-12.

9. Ardestani A, Yazdanparast R. Cyperus rotundus suppresses AGE formation and protein oxidation in a model of fructose mediated protein glycoxidation. Int $\mathrm{J}$ Biol Macromol. 2007;41(5):572-8.

10. Wittenauer J, Mäckle S, Sußmann D, Schweiggert-Weisz U, Carle R. Inhibitory effects of polyphenols from grape pomace extract on collagenase and elastase activity. Fitoterapia. 2015;101:179-87.

11. Thring TSA, Hili P, Naughton DP. Anti-collagenase, anti-elastase and anti-oxidant activities of extracts from 21 plants. BioMed Central. 2009;9:1-11.

12. Kanashiro A. Elastase release by stimulated neutrophils inhibited by flavonoids: importance of the catechol group. Zeitschrift für Naturforschung C. 2007; $56: 357-61$

13. Doughari JH. Phytochemicals: Extraction methods, basic structures and mode of action as potential chemotherapeutic agents. In: Rao $\mathrm{V}$, editors Phytochemicals - a global perspective of their role in nutrition and health Shanghai (China): Intech. 2012;1-33.

14. Obouayeba AP, Diarrassouba M, Soumahin EF, Kouakou H. Phytochemical analysis, purification and identification of hibiscus anthocyanins. J Pharm Chem Biol Sci. 2015;3(2):156-68.

15. Iqbal E, Salim KA, Lim LB. Phytochemical screening, total phenolics and antioxidant activities of bark and leaf extracts of Goniothalamus velutinus (Airy Shaw) from Brunei Darussalam. Journal of King Saud University - Science. 2015:27(3):224-32.

16. Banu KS, Catherine L. General techniques involved in phytochemical analysis IJARCS. 2015;2(4):25-32.

17. Al-Jumaily, Essam FA, Jameelah KT Al-Isawi. Chemical composition and antioxidant potential of polyphenol compounds of Cyperus rotundus $\mathrm{L}$. rhizomes. Genetic Engineering and Biotechnology Institute for postgraduate Studie. 2008;28(6):2321-748.

18. Brás N, Gonçalves R, Mateus N, Fernandes P, Ramos M, de Freitas V. Inhibition of pancreatic elastase by polyphenolic compounds. J Agric Food Chem. 2008;58(19):10668-76. 


\section{GRAPHICAL ABSTRACT}

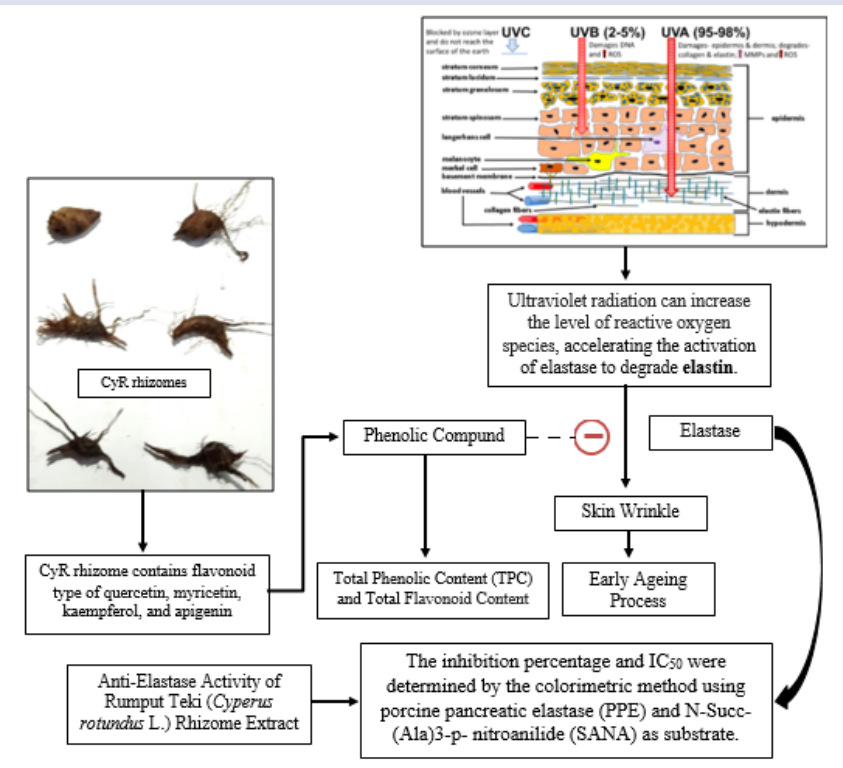

\section{SUMMARY}

The extract of CyR rhizomes contained TPC and TFC of $62.72 \mathrm{mg} \mathrm{GAE} / \mathrm{g}$ and $10.72 \mathrm{mgEQ} / \mathrm{g}$ extract respectively and showed an inhibitory activity on elastase with $\mathrm{IC}_{50}$ of 178.72 $\mu \mathrm{g} / \mathrm{mL}$, smaller than $\mathrm{IC}_{50}$ of quercetin as reference drug $(200.00 \mu \mathrm{g} / \mathrm{mL})$. This finding suggested that extract of CyR rhizomes could be used as elastase inhibitor but the further research still needs to be developed.

Cite this article: Putri IR, Handayani R, Elya B. Anti-Elastase Activity of Rumput Teki (Cyperus rotundus L.) Rhizome Extract. Pharmacog J. 2019;11(4):754-8. 